WMJ (Warmadewa Medical Journal), Vol. 6 No. 2 November 2021, Hal. 61-66

\title{
Prevalence and Characteristics of Tubectomy Contraceptive Users in Bali from 2019-2020
}

\author{
I Gusti Ngurah Rama Krishna ${ }^{1}$, I Made Wandia ${ }^{2}$, Putu Nita Cahyawati ${ }^{3 *}$ \\ ${ }^{I}$ Undergraduate student, Faculty of Medicine and Health Sciences Universitas Warmadewa \\ ${ }^{2}$ Departement of Obstetrics and Gynecology, RSUD Sanjiwani \\ ${ }^{3}$ Departement of Pharmacology and Pharmacy, Faculty of Medicine and Health Sciences Universitas Warma- \\ dewa \\ *Email: putunitacahyawati@gmail.com
}

\begin{abstract}
Indonesia is the country with the largest population in Southeast Asia. The total population in Indonesia was recorded at 255.18 million, with a population growth rate of 3.33 million every year. This population growth has an impact on the economic development and welfare of the country. One of the efforts to suppress the increasing population is to use tubectomy contraception. This study aims to determine the characteristics of tubectomy contraceptive users in Bali in 2019-2020. The design of this research was descriptive crosssectional. The inclusion criteria in this study were tubectomy contraceptive acceptors recorded in the medical records of the Sanjiwani Hospital in the range of 2019 to 2020. The exclusion criteria were incomplete medical record data. The results of this study found that the prevalence of tubectomy users at the Sanjiwani Hospital from January 2019 to September 2020 was 6.71\%. Characteristics of the most users are 36-45 years old, as many as 32 people (65.3\%), the highest number of children are 3 children, namely 22 people (44.8\%), the highest education level was high school level, which is 24 people (49\%), the most occupations are housewives as many as 32 people (65.3\%), the most common type of tubectomy was postpartum tubectomy as many as 40 people (81.6\%), and for insurance, the most is a Surat Keterangan Tidak Mampu (SKTM) which is as many as 27 people $(55,1 \%)$. This study concludes that the characteristics of the most contraceptive users are 36-45 years old, the highest number of children are 3 children, the highest education is senior high school, the majority are IRT, the most type of tubectomy contraception is postpartum, and the majority of insurance used is SKTM.
\end{abstract}

Keywords : contraception, tubectomy, RSUD Sanjiwani, Bali

\section{Abstrak \\ [Prevalensi dan Karakteristik Pengguna Kontrasepsi Tubektomi di Bali Tahun 2019-2020]}

Indonesia menjadi negara dengan populasi penduduk terbanyak di Asia Tenggara. Jumlah penduduk di Indonesia tercatat sebesar 255,18 juta, dengan laju pertumbuhan penduduk sebesar 3,33 juta setiap tahun. Pertumbuhan penduduk ini berdampak terhadap perkembangan ekonomi dan kesejahteraan negara. Salah satu upaya untuk menekan angka peningkatan jumlah penduduk ini adalah dengan menggunakan kontrasepsi tubektomi. Penelitian ini berujuan untuk mengetahui karakteristik pengguna kontrasepsi tubektomi di Bali pada tahun 2019-2020. Desain penelitian ini adalah deskriptif cross-sectional. Kriteria inklusi pada penelitian ini adalah akseptor kontrasepsi tubektomi yang tercatat pada rekam medis RSUD Sanjiwani dalam rentang tahun 2019 hingga 2020. Adapun kriteria eksklusi berupa kurang lengkapnya data rekam medis. Hasil penelitian ini menemukan bahwa prevalensi pengguna tubeketomi di RSUD Sanjiwani dari Januari 2019 hingga September 2020 adalah 6,71\%. Karakteristik pengguna terbanyak adalah usia 36-45 tahun yaitu sebanyak 32 orang $(65,3 \%)$, jumlah anak terbanyak adalah 3 anak yaitu sebanyak 22 orang $(44,8 \%)$, pendidikan terbanyak adalah tingkat SMA yaitu sebanyak 24 orang (49\%), pekerjaan terbanyak adalah ibu rumah tangga yaitu sebanyak 32 orang $(65,3 \%)$, jenis tubektomi tersering adalah tubektomi postpartum yaitu sebanyak 40 orang $(81,6 \%)$, dan untuk asuransi yang terbanyak adalah Surat Keterangan Tidak Mampu (SKTM) yaitu sebanyak 27 orang $(55,1 \%)$. Kesimpulan penelitian ini adalah karakteristik pengguna kontrasepsi terbanyak adalah usia 36-45 tahun, jumlah anak terbanyak adalah 3 anak, pendidikan terbanyak adalah SMA, mayoritas adalah IRT, jenis kontrasepsi tubektomi terbanyak adalah postpartum, dan mayoritas asuransi yang digunakan adalah SKTM.

Kata kunci: kontrasepsi, tubektomi, RSUD Sanjiwani, Bali 


\section{BACKGROUND}

In the last 15 years, increasing Indonesia's population has reached 3.33 million people per year. Indonesia was recorded to have had a total population of 255.18 million people in 2015. ${ }^{1}$ This condition directly affects the country's economic, education, and social welfare sectors. ${ }^{2}$

Therefore, the National Population and Family Planning Agency (BKKBN) was formed, which its main task is to reduce Indonesia's population growth rate below $1 \%$ and cut down the female fertility rate by 0.4 , from an initial value of 2.6 to 2.2. Total 7.1 million new acceptors were targeted to join the family planning (KB) program. However, this target is not being reached yet. Data from the BKKBN Strategic Plan in 2018 shows that the female fertility rate in Indonesia is still at 2.38, which is certainly still above the target set. ${ }^{3}$

Couples of childbearing age (PUS) in Indonesia were reported to have reached more than 38 million people in 2018, with the number of active family planning users (acceptors) being 63.27\%. These acceptors include $7.35 \%$ using an intrauterine device (IUD), $2.76 \%$ tubectomy, $0.5 \%$ using the male operative method (MOP), 7.2\% using implants, $63.71 \%$ injections, and $17.24 \%$ utilizing pills, and $1.24 \%$ with condoms. ${ }^{4}$ The unmet need is also reported as still high. It reached $8.2 \%$ in 2012 . It only decreased by $0.1 \%$ compared to the results achieved ten years ago. The unmet need community does not receive any services related to the family planning program, which need to be solved immediately.

Data on users of long-term contraceptive methods (MKJP) in 2018 was reported to be around $17.8 \%$ and increased to $24.6 \%$ in 2019 . However, tubectomy contraception is the lowest of the various available MKJP options. ${ }^{4}$ Based on this issue, further research is needed to determine the prevalence and characteristics of tubectomy contraceptive users in Bali, especially in the Sanjiwani Hospital, Gianyar.

\section{METHOD}

This research has ethical approval from the Health Research Ethics Commission (KEPK) of Warmadewa University, 134/Unwar/FKIK/KEPK/VIII/2020. This research is a descriptive study. Samples were from the medical record of RSUD Sanjiwani Gianyar from January 2019 to September 2020, and forty-nine samples were selected. The inclusion criteria were acceptors who were certain to do tubectomy, recorded in the medical records, and the exclusion criteria were patients with incomplete medical record data. In addition, this study's variables were: age, the number of children, education, occupation, type of tubectomy contraception, and insurance used. The results will be presented in the form of tables and narratives.

\section{RESULTS}

Based on medical records at the Sanjiwani Hospital Gianyar, 730 new family planning acceptor users were from January 2019 to September 2020, with details of IUD acceptors 573 people $(78.4 \%)$, tubectomy 49 people $(6.7 \%)$, implants 14 people $(1.9 \%), 23$ with condoms $(3.1 \%)$, injections 65 people $(8.9 \%)$, and six with pills $(0.8 \%)$. While the previous family planning acceptors were 701 people, with details of IUD acceptor 96 people (13.6\%), tubectomy 33 people $(4.7 \%)$, implants nine people $(1.2 \%)$, condoms 42 people $(6 \%)$, injections 514 people $(73.3 \%)$, and pills seven people $(1 \%)$.

These results indicate that the percentage of new and previous tubectomy acceptors at the Sanjiwani Hospital is still below 7\%. The prevalence of tubectomy users at the Sanjiwani Hospital in 20192020 was $6.71 \%$ (49 people) out of 730 new family planning acceptors.

\section{Age}

The distribution of tubectomy contraception users were 13 people with age between 26-35 years old (26,5\%), 32 people with age $36-45$ years old, and four people between $46-55$ period (table 1 ). 
Table 1. age distribution

\begin{tabular}{|c|c|c|}
\hline Age & Frequency (n) & Presentage $(\%)$ \\
\hline $26-35$ & 13 & 26,5 \\
\hline $36-45$ & 32 & 65,3 \\
\hline $46-55$ & 4 & 8,2 \\
\hline \multicolumn{3}{|c|}{$\begin{array}{l}\text { Number of Children } \\
\text { The distribution of the number of } \\
\text { children owned by tubectomy contraception } \\
\text { users in this study was } 2 \% \text { (one child), } \\
12.3 \% \text { (two children), } 44.8 \% \text { (three } \\
\text { children), } 28.6 \% \text { (four children), and } 12.3 \% \\
\text { (more than five children) (Table } 2 \text { ). }\end{array}$} \\
\hline Table 2 . The dist & on $\mathrm{o}$ & of children \\
\hline $\begin{array}{c}\text { Number of chil- } \\
\text { dren }\end{array}$ & Frequency (n) & Percentage $(\%)$ \\
\hline 1 & 1 & 2 \\
\hline 2 & 6 & 12,3 \\
\hline 3 & 22 & 44,8 \\
\hline 4 & 14 & 28,6 \\
\hline 5 & 6 & 12,3 \\
\hline
\end{tabular}

\section{Education}

The distribution of education background of the samples was $8,2 \%$ (4 people with elementary school background), 40,8\% (20 people with junior high school background), 49\% (24 people with senior high school background), 2\% (1 person with bachelor background) (Table 3 ).

Table 3. The Distribution of Educational Background

\begin{tabular}{lll}
\hline Education & Frequency (n) & Percentage (\%) \\
\hline Elementary & 4 & 8,2 \\
Junior High & 20 & 40,8 \\
Senior High & 24 & 49 \\
Bachelor & 1 & 2 \\
\hline
\end{tabular}

\section{Employment Status}

The distribution of employment status among the samples was 20,4\% (10 people) as a entrepreneur, 65,3\% (32 peo- ple) as a housewife, and 14,3\% (7 people) as a daily worker. None of them work as a civil servant (Table 4).

Table 4. The Distribution of Employment Status

\begin{tabular}{lll}
\hline $\begin{array}{l}\text { Employment Sta- } \\
\text { tus }\end{array}$ & Frequency (n) $\begin{array}{l}\text { Percentage } \\
(\%)\end{array}$ \\
\hline Civil Servant & 0 & 0 \\
Entrepreneur & 10 & 20,4 \\
Housewife & 32 & 65,3 \\
Daily Worker & 7 & 14,3 \\
\hline
\end{tabular}

\section{Type of Tubectomy Contraception Used}

The distribution of tubectomy contraception used in this study was $81,6 \%$ (40 people) using postpartum, $12,3 \%$ (6 people) using interval, and $6,1 \%$ (3 people) using postsectiocessaria (Table 5).

Table 5. The Distribution of Tubectomy Contraception Used

\begin{tabular}{ccc}
\hline Types & Frequency (n) & $\begin{array}{c}\text { Percentage } \\
(\%)\end{array}$ \\
\hline Postpartum & 40 & 81,6 \\
Interval & 6 & 12,3 \\
Postsectiocessaria & 3 & 6,1 \\
\hline
\end{tabular}

\section{Health Insurance}

The distribution of health insurance used by the samples in this study was $10,2 \%$ (5 people) without insurance (general), 30,6\% (15 people) using national health insurance - BPJS, 55,1\% (22 people) owned certificate of incapacity (SKTM), and $4,1 \%$ (2 people) using Jampersal (Table 6).

Table 6. The Distribution of Health Care Insurance Used

\begin{tabular}{ccc}
\hline Types & Frequency (n) & $\begin{array}{c}\text { Percentage } \\
(\%)\end{array}$ \\
\hline General & 5 & 10,2 \\
BPJS & 15 & 30,6 \\
SKTM & 27 & 55,1 \\
Jampersal & 2 & 4,1 \\
\hline
\end{tabular}




\section{DISCUSSION}

Age

This study found that mostly the acceptors were in the age range of 36-45 years $(65.3 \%)$. This result is similar to a study conducted in Surabaya where the age of most of the acceptors was 35-39 years old $(41 \%)^{6}$

This finding is also in line with the goals of contraception according to the World Health Organization (WHO). WHO states that women have 3 reproductive phases, namely: the phase of delaying pregnancy (age under 20 years), the phase of spacing out pregnancies (age 20-30 years), and the phase of ending fertility with (age over 30 years, especially in women over 35 years old). In the termination phase of fertility, the woman is assumed to have had enough children, so it is not recommended to have another child due to medical or other non-medical reasons. Thus, in this phase, the best contraceptive method is tubectomy as a steady and permanent contraception.

\section{Number of Children}

The study found that the acceptors were mostly women who had 3 children $(44.8 \%)$. This is similar to a previous study which also found that the most tubectomy family planning acceptors were those who had 3-4 children $(57 \%){ }^{6}$

The number of children affects the type of contraception to be used. PUS tends to choose contraception with lower effectiveness when they have a few children, while PUS who have more children tend to use contraception with a higher level of effectiveness, such as using MKJP, including this tubectomy.

\section{Educational Background}

The highest use of tubectomy contraception in this study was in women with a high school education background (49\%). This result is also similar to a study in 2012 conducted at the dr Pirngadi Regional General Hospital in Medan. The results of the study stated that the most acceptors were mothers with a high school education level of $60.3 \%{ }^{10}$
The level of education plays an important role in the decision making, including the use of contraception. Women with a higher level of education will tend to have broader knowledge, and understand new thoughts/perspective/information better, more independent, and can think more rationally. ${ }^{11}$

Education also affects the mindset and decision-making related to the period of reproduction or fertility. Education can be the cause of a woman delaying her pregnancy, especially when she wants to continue her education to a higher level. Therefore, it is not uncommon for a woman to delay marriage, so that her reproductive period becomes shorter. ${ }^{12}$

\section{Employment Status}

The study found that the acceptors who worked were less than those who did not. This is in accordance with the results of research conducted at Pukesmas Jombang, South Tangerang, where the percentage of acceptors who do not work is $76.8 \%{ }^{13}$

Employment status has an impact on a person's economic level. People who have jobs will be able to earn income that can be used to provide their daily needs. ${ }^{(14)}$ However, it seems that employment status have no effect in choosing tubectomy contraception. The role of other factors such as age and number of children are more likely to be dominant.

However, employment status is closely related to a person's level of education and knowledge. Employment status may affect a person's risk of experiencing a sexually transmitted disease (HIV/AIDS). (15) In this condition, tubectomy is not a contraceptive method that can prevent the disease, but other types of contraception such as condoms. Therefore, efforts to increase knowledge and empower the community are a solution to overcome this problem. ${ }^{16}$

\section{Type of Tubectomy}

A study in the United States states that the postpartum is the most common tubectomy performed, based on the length 
of hospital stay and also the less common complications compared to interval tubectomy. Postpartum sterilization within 8 hours after delivery can be done if the delivery has no complications and the mother's health history is good. However, sterilizing this early after delivery does not allow enough time to properly assess the newborn. The decision to continue sterilization in a high-risk patient should be considered if a subsequent pregnancy could result in maternal morbidity or mortality. Staff availability is another consideration as procedures should not be performed if they could interfere with other aspects of patient care. $^{17}$

\section{Healthcare Insurace}

Based on the types of health insurance in this study, it showed that insurance is not a single factor in the selection of tubectomy contraception. Medical reasons, age and number of children should also be considered in making decisions in the choice of contraception. In addition, this study was only conducted at the Sanjiwani Hospital which is a government hospital, so it is likely that most of the patients were referral patients from first-level health services.

\section{CONCLUSION}

The prevalence of tubectomy contraceptive users at the Sanjiwani Hospital in 2019-2020 is $6.71 \%$. The characteristics of the most contraceptive users are 36-45 years old with high school background working as housewife. Most of them have 3 children and chose to have postpartum tubectomy with majority used SKTM to get healthcare insurace.

\section{ACKNOWLEDGMENT}

The authors would like to thank the Sanjiwani Hospital Gianyar and the Faculty of Medicine and Health Sciences, Warmadewa University, who have supported and facilitated this research. The author declares that there is no conflict of interest in this research.

\section{REFERENCES}

1. Nurani; Wahyuni; S, Windiarto; T, Oktavia; E, Karyono; Y. Profil Penduduk Indonesia Hasil Supas 2015. Jakarta: Badan Pusat Statistik; 2016.

2. Irianto K. Pelayanan Keluarga Berencana Dua Anak Cukup: Kontrasepsi Untuk Mencapai Target Keluarga Berencana Global/Koes Irianto Cetakan 1. Bandung: Alfabeta; 2014.

3. Badan Kependudukan dan Keluarga Berencana Nasional. Rencana Strategis Badan Kependudukan dan Keluarga Berencana Nasional tahun 2015-2019. BKKBN Provinsi Riau; 2017.

4. Kementrian Kesehatan Republik Indonesia. Profil Kesehatan Indonesia 2018. Jakarta: Kementrian Kesehatan RI. 2019.

5. Jurisman A, Ariadi A, Kurniati R. Hubungan Karakteristik Ibu dengan Pemilihan Kontrasepsi di Puskesmas Padang Pasir Padang. Jurnal Kesehatan Andalas 2016; 5(1):1915.

6. Grestanti L, Firtriyah N. Identifikasi Faktor Keikutsertaan Akseptor Tubektomi Kota Surabaya Di Klinik PKBI Jawa Timur. Jurnal Biometrika dan Kependudukan 2018; $7: 49-58$.

7. Hidayati E. Kesehatan Perempuan Dan Perencanaan Keluarga Cetakan 1. Jakarta: Fakultas Kedokteran dan Kesehatan Universitas Muhammadiyah: Jakarta; 2017.

8. Fitrianingsih ADR, Melaniani S. Faktor Sosiodemografi yang Memengaruhi Pemilihan Metode Kontrasepsi. Jurnal Biometrika dan Kependudukan 2016; 5(1):10-8.

9. Dewiyanti N. Hubungan Umur Dan Jumlah Anak Terhadap Penggunaan Metode Kontrasepsi Di Puskesmas 
Bulak Banteng Surabaya. Medical Technology and Public Health Journal 2020;4(1):70-8.

10. Herlinawati H, Fitria M, Santosa H. Faktor-Faktor Yang Berhubungan Dengan Pemakaian Kontrasepsi Tubektomi Pada Wanita Pasangan Usia Subur Di RSUD Dr Pirngadi Medan Tahun 2012. 2012; 1-10.

11. Aningsih BSD, Irawan YL. Hubungan Umur, Tingkat Pendidikan, PEkerjaan dan Paritas Terhadap Penggunaaan Metode Kontrasepsi Jangka Panjang (MKJP) Di Dusun III Desa Pananjung Kecamatan Cangkuang Kabupaten Bandung. Jurnal Kebidanan. 2019;8(1):33-40.

12. Ruri R, Julaeni R. Faktor-Faktor Yang Memengaruhi Penundaan Kelahiran Anak Pertama Di Wilayah Perdesaan Indonesia: Analisis Data SDKI 2012. Jurnal Kependudukan Indonesia 2017;12(1):2000-10.

13. Huda AN, Widagdo L, Widjanarko B. Faktor-Faktor Yang Berhubungan Dengan Perilaku Penggunaan Alat Kontrasepsi Pada Wanita Usia Subur
Di Puskesmas Jombang-Kota Tangerang Selatan. Jurnal Kesehatan Masyarakat Universitas Diponegoro 2016; 4(1): 461-469.

14. Thamrin KMH, Bashir A. Persepsi Seseorang Dalam Memilih Pekerjaan Sebagai Dosen Perguruan Tinggi Negeri Di Indonesia. Jurnal Manajemen dan Bisnis Sriwijaya 2015; 13(3):397-412.

15. Pradnyawati LG, Cahyawati PN. Qualitative Study: High-Risk Sexual Behavior and Prevention of STD and HIV/AIDS Among Female Sellers at Sindhu Market Sanur, Bali. WMJ 2019; 4(1):14-20.

16. Pradnyawati LG, Cahyawati PN, Permatananda PANK. Pemberdayaan Kader dalam Pencegahan IMS dan HIV/AIDS pada Pedagang Perempuan di Kota Denpasar. Paradharma. 4 (2): $145-150$

17. Lydon-Rochelle M, Holt VL, Martin DP, Easterling TR. Association Between Method of Delivery and Maternal Rehospitalization. JAMA 2000; 283(18):2411-6. 